\title{
Genistein exerts growth inhibition on human osteosarcoma MG-63 cells via PPAR $\gamma$ pathway
}

\author{
MINGZHI SONG ${ }^{1,2}$, XILIANG TIAN ${ }^{1}$, MING LU $^{1}$, XIANBIN ZHANG ${ }^{3}$, KAI MA $^{1}$, ZHICHAO LV $^{1}$, \\ ZHENXING WANG ${ }^{1}$, YANG HU ${ }^{1}$, CHONG XUN ${ }^{1,2}$, ZHEN ZHANG $^{1 *}$ and SHOUYU WANG ${ }^{*}$ \\ ${ }^{1}$ Department of Orthopaedics, The First Affiliated Hospital of Dalian Medical University, Dalian, Liaoning 116011; \\ ${ }^{2}$ Department of Orthopaedics, The Third Affiliated Hospital of Dalian Medical University, Dalian, Liaoning 116200; \\ ${ }^{3}$ Department of Hepatobiliary Surgery, The First Affiliated Hospital of Dalian Medical University, \\ Dalian, Liaoning 116011, P.R. China
}

Received October 17, 2014; Accepted December 3, 2014

DOI: 10.3892/ijo.2015.2829

\begin{abstract}
The peroxisome proliferator-activated receptor $\gamma$ $(\operatorname{PPAR} \gamma)$ is emerging as an important regulator in various metabolic processes of cancer. Genistein, as a major isoflavonoid isolated from dietary soybean, possesses a wide variety of biological activities, particularly, in cancer prevention. However, the mechanisms by which genistein elicits its growth inhibiting effects in osteosarcoma (OS) MG-63 cells have not been extensively elucidated. MG-63 cells were treated for 2 days with various concentrations of genistein and/or GW9662 (a selective antagonist of PPAR $\gamma$ ). The effect of different drugs on cell viability was determined by Cell Counting Kit- 8 (CCK-8). The assay of cell proliferation was performed using 5-ethynyl-2'-deoxyuridine (EdU). The changes of apoptosis and cell cycle progression were detected by flow cytometry experiments. The protein expression of PPAR $\gamma$ pathway (PPAR $\gamma$, PTEN, BCL-2, Survivin, P21 ${ }^{\mathrm{WAF} / / C I P 1}$ and Cyclin B1) was determined by western blot analysis. The expression of PPAR $\gamma$ and PTEN mRNA was detected by real-time quantitative RT-PCR analysis. We report that genistein caused OS cell growth inhibition. We found that the PPAR $\gamma$ expression in OS cells increased after genistein treatment. Further studies on the mechanisms of genistein revealed a series of cell growth changes related to the PPAR $\gamma$ pathway; while cell cycle changes can be reversed by GW9662. Genistein plays an important role in preventing OS cell growth, which can impede the OS cell cycle as a non-toxic activator of PPAR $\gamma$, providing novel insights into the mechanisms of the therapeutic activities of genistein.
\end{abstract}

Correspondence to: Dr Zhen Zhang or Dr Shouyu Wang, Department of Orthopaedics, The First Affiliated Hospital of Dalian Medical University, 222 Zhong Shan Road, Dalian, Liaoning 116011, P.R. China E-mail: doctorzz@126.com

E-mail:dmuwsy@sina.com

*Contributed equally

Key words: genistein, osteosarcoma, PPAR $\gamma$, PTEN, cell proliferation, cell cycle

\section{Introduction}

Genistein (4',5,7-trihydroxyisoflavone) is a common type of isoflavone that is abundantly found in soy products, which exerts diverse biological activities (1). Genistein is believed to have a potent antitumor activity in various cancer cell lines (2-7). It has attracted attention due of its extensive chemotherapeutic functions for malignancies and its minimal side effects. Genistein has inhibitory effects on the growth, survival, metastasis, invasion and angiogenesis of cancer cells, by inhibiting cell proliferation and inducing apoptosis (8-11). In 1996, the pioneering study by Yamashita et al indicated that genistein could intervene in OS cell lines (12). Subsequent reports from these authors demonstrated that this flavonoid compound has antitumor effects on human OS cell lines (13-16). Additionally, it has been found that genistein decreased cell invasion and motility potentials by inducing cell differentiation in murine OS cell line LM8 (17). Recently, there have been significant interests in exploring malignancy specific receptors activated by genistein - including in OS.

Genistein is known as a phytoestrogen that has the ability to bind with an estrogen receptor (ER) (18). Previous studies on OS cells suggested that genistein can affect multiple intracellular events by binding different ER isoforms $(13,19)$ and that its inhibition becomes statistically significant from $1 \mathrm{nmol} / 1$ (20). The specific inhibition of genistein on the epidermal growth factor receptor protein tyrosine kinase (PTK) is a well-known mechanism (21). Genistein has also shown antiproliferative effects on OS cells, which is probably due to its anti-PTK mechanism (5).

I was proposed that phytoestrogens might act through nuclear receptors other than ERs, and genistein was reported to act as a natural ligand of PPAR $\gamma(22)$, provoking PPAR $\gamma$ dependent gene transcription (23) and regulating the PPAR $\gamma$ signaling pathway (24). In addition, a high concentration genistein treatment $(>1 \mu \mathrm{mol} / \mathrm{l})$ can bind with PPAR $\gamma$ and downregulate osteogenesis, which is consistent with the effects of inducing PPAR $\gamma$ (22).

PPAR $\gamma$, an isotype of PPARs, is a ligand-dependent transcription factor of the nuclear hormone receptor superfamily (25). It regulates gene transcription in multistep metabolic 
processes, such as lipid, glucose homeostasis, inflammation $(26,27)$ and tumorigenesis (28). It has aroused remarkable interests due to its antitumor effects against a variety of malignancies (29-36). Increasing evidence demonstrates that PPAR $\gamma$ activation may be sought as a probable intervention in OS (37-41). PPAR $\gamma$ agonists can promote osteoblastic differentiation of OS cells (42) and suppress its proliferation (43). Moreover, several novel natural compounds, which have PPAR $\gamma$ agonistic activities, possess potent antitumor activities. Therefore, one future direction of this study is to develop a safe and effective PPAR $\gamma$ agonist that can be used as a chemopreventive agent for OS patients.

The therapeutic potential of genistein as an antitumor agent is clearly evident. However, it is not clear whether genistein is involved with the antitumor activities of OS cells by directly activating PPAR $\gamma$. Thus, we explored the effects of genistein on OS cell viability via PPAR $\gamma$ pathway and investigated the potential underlying mechanisms.

\section{Materials and methods}

Reagents and antibodies. Genistein (4',5,7-trihydroxyisoflavone), 2-chloro-5-nitrobenzanilide (GW9662), dimethyl sulfoxide (DMSO), Triton X-100, RNase A and propidium iodide (PI) were all purchased from Sigma-Aldrich Corp. (Sigma-Aldrich Corp., St. Louis, MO, USA). Dissolving genistein and GW9662 in DMSO were recommended. According to the product information, genistein was dissolved to prepare a $10 \mathrm{mg} / \mathrm{ml}$ stock solution and GW9662 was reconstituted as a $26 \mathrm{mg} / \mathrm{ml}$ stock solution. The solutions were then diluted to appropriate concentrations with a culture medium. Dulbecco's modified Eagle's medium (DMEM), penicillin-streptomycin, trypsin-EDTA, trypsin and fetal bovine serum (FBS) were all obtained from Gibco/Life Technologies (Carlsbad, CA, USA). Rabbit polyclonal antibodies specific for PPAR $\gamma$, phosphatase and tensin homolog (PTEN), P21 ${ }^{\mathrm{WAF} 1 / \mathrm{CIP} 1}$, Cyclin B1, B-cell lymphoma-2 (BCL-2), survivin and mouse monoclonal antibody specific for $\beta$-actin were purchased from Assay Biotechnology (Sunnyvale, CA, USA). Horseradish peroxidase-conjugated goat anti-mouse and goat anti-rabbit secondary antibodies were obtained from Santa Cruz Biotechnology, Inc. (Santa Cruz, CA, USA).

Cell and cell culture. The MG-63 OS cell line was purchased from the China Center Type Culture Collection (CCTCC, Shanghai, China). The cells have been maintained under standard culture conditions in DMEM, supplemented with $10 \%$ (vol/vol) FBS and $1 \%$ pencillin-streptomycin at $37^{\circ} \mathrm{C}$, under a humidified atmosphere of $5 \% \mathrm{CO}_{2}$ in our laboratory. The medium was replaced every 3 days before full confluency.

Cytotoxicity assay. Cells were seeded with a density of $2-4 \times 10^{3} /$ well in 96-well plates, which was allowed to attach overnight. The medium was replaced with a fresh medium containing different concentrations of genistein (0-120 $\mu \mathrm{mol} / \mathrm{l}$ or GW9662 0-100 $\mu \mathrm{mol} / \mathrm{l}$ ), diluted from the stock solution. Since the final DMSO concentration of genistein in the medium was $>0.1 \%$, a DMSO (solvent) concentration of $0.32 \%$ ( $\mathrm{vol} / \mathrm{vol}$ ) was used for vehicle control. After 24, 48 and $72 \mathrm{~h}$ of incubation, $10 \mu \mathrm{l}$ of Cell Counting Kit-8 (CCK-8) (Dojindo,
Tokyo, Japan) solution was added. Absorbance at $450 \mathrm{~nm}$ was measured by the Microplate Reader (Thermo Labsystems, Helsinki, Finland). The relative folds of drug resistance were analyzed by comparing with $\mathrm{IC}_{50}$.

As stated above, cells were plated and allowed to attach overnight; the medium was then removed and replaced with a fresh medium containing various doses of genistein $(40,60$ and $80 \mu \mathrm{mol} / \mathrm{l})$, with $1 \mu \mathrm{mol} / 1$ of GW9662, for $48 \mathrm{~h}$. The effect of GW9662 on cell viability was examined by CCK-8 method, as described above.

Cell proliferation assay. The proliferation assay of MG-63 cells was performed using a Cell-Light ${ }^{\mathrm{TM}}$ 5-ethynyl-2'-deoxyuridine (EdU) DNA Cell Proliferation kit (Ruibo Biotech, Guangzhou, China), based on the manufacturer's protocols (44-46). MG-63 cells were cultured in 24-well plates at $2-3 \times 10^{4} /$ well with different concentrations of genistein $(40,60$ and $80 \mu \mathrm{mol} / \mathrm{l})$, with or without GW9662 (1 $\mu \mathrm{mol} / \mathrm{l})$, for $48 \mathrm{~h}$. Then, the cells were incubated with $100 \mu \mathrm{mol} / 1$ of EdU for another $2 \mathrm{~h}$. Finally, the cells were fixed with $4 \%$ formaldehyde in phosphate buffered solution (PBS) buffer solution, for $30 \mathrm{~min}$. After labeling, five random x 100 fields were photographed in each well. The EdU-positive cells were counted, averaged and compared. Assays were performed three times using triplicate wells.

Annexin V-FITC/PI double staining. To measure the apoptosis rate of the cells, we used the Annexin V-FITC/PI doublefluorescence apoptosis detection kit (Biouniquer Technology, Shanghai, China). Briefly, the cells were seeded in 6-well plates $\left(2 \times 10^{5}\right.$ cells $\left./ \mathrm{ml}\right)$ and exposed to genistein $(40,60$ and $80 \mu \mathrm{mol} / \mathrm{l})$, with or without GW9662 $(1 \mu \mathrm{mol} / \mathrm{l})$, for $48 \mathrm{~h}$. The cells were washed 2 times by PBS buffer solution at $4^{\circ} \mathrm{C}$, diluted with $500 \mu \mathrm{l}$ of Annexin $\mathrm{V}$ binding liquid and $5 \mu \mathrm{l}$ of Annexin V-FITC was added at $4^{\circ} \mathrm{C}$ for $15 \mathrm{~min}$ in the dark. Finally, $10 \mu \mathrm{l}$ of PI was added at $4^{\circ} \mathrm{C}$ for $5 \mathrm{~min}$ in the dark. Samples were analyzed using a FACScan flow cytometer (Becton-Dickinson, San Jose, CA, USA) - within $1 \mathrm{~h}$ after staining.

Cell cycle progression. MG-63 cells were plated in $\mathrm{T}_{25}$ tissue culture flasks at $2 \times 10^{6} /$ flask in a culture medium. After $24 \mathrm{~h}$, cells were washed in PBS buffer and treated with a fresh medium, with or without $1 \mu \mathrm{mol} / 1$ of GW9662 or various concentrations of genistein (40,60 and $80 \mu \mathrm{mol} / \mathrm{l})$. Following $48 \mathrm{~h}$ of genistein treatment, the cells were detached and trypsinized and washed two times in PBS buffer solution at $4^{\circ} \mathrm{C}$. Then, the cells were fixed and permeabilized with $70 \%$ ethanol on ice for $2 \mathrm{~h}$. Cells were washed again in $0.5 \mathrm{ml}$ of PBS buffer solution and stained for $30 \mathrm{~min}$ with $1 \mathrm{ml}$ of DNA fluorochrome solution at normal temperature, containing $200 \mu \mathrm{g}$ of PI, $0.1 \%$ of Triton X-100 and $2 \mathrm{mg}$ of RNase A. Then $2 \times 10^{4}$ cells were counted and analyzed using a FACScan flow cytometer (Becton-Dickinson).

Western blot analysis. The $2 \times 10^{6}$ cells that were treated for $48 \mathrm{~h}$ with genistein $(40,60$ and $80 \mu \mathrm{mol} / \mathrm{l})$ and/or GW9662 ( $1 \mu \mathrm{mol} / \mathrm{l})$ were washed twice in an ice-cold PBS buffer solution; and the cells were resuspended in $200 \mu \mathrm{l}$ of ice-cold lysis buffer solution $(50 \mathrm{mmol} / \mathrm{l}$ Tris- $\mathrm{HCl}, 150 \mathrm{mmol} / \mathrm{l} \mathrm{NaCl}$, $0.02 \% \mathrm{NaN}_{3}$ and $1 \% \mathrm{NP}_{40}$ ) for $30 \mathrm{~min}$. The lysates were 
Table I. Primers used for real-time PCR.

\begin{tabular}{llll}
\hline Gene & Priners & Sequences & GenBank \\
\hline PPAR $\gamma$ & Forward & 5'-ATTCCATTCACAAGAACAGATCCAG-3' & NM_005037.5 \\
& Reverse & 5'-TTTATCTCCACAGACACGACATTCA-3' & \\
PTEN & Forward & 5'-GAGCGTGCAGATAATGACAAGGAAT-3' & NM_000314.4 \\
& Reverse & 5'-GGATTTGACGGCTCCTCTACTGTTT-3' & \\
$\beta$-actin & Forward & 5'-CATTGCCGACAGGATGCA-3' & NM_001101.3 \\
& Reverse & 5'-CATCTGCTGGAAGGTGGACAG-3' & \\
\hline
\end{tabular}

clarified by centrifugation for $15 \mathrm{~min}$ at $14,000 \mathrm{rpm}$ at $4^{\circ} \mathrm{C}$. The protein concentration of the supernatants was determined by using a bicinchoninic acid protein assay (Pierce, Rockford, IL, USA). Equal amounts of lysate protein were separated by 8-12\% SDS-polyacrylamide gel electrophoresis, which were then transferred onto polyvinylidene fluoride membranes. After being blocked with $10 \%$ non-fat dry milk for $1 \mathrm{~h}$ at room temperature, the membranes were washed three times with a PBS Tween-20 (PBST) buffer solution and incubated with monoclonal antibodies or phosphorylated antibodies overnight, at $4^{\circ} \mathrm{C}$. Subsequently, the membranes were washed three times with PBST buffer solution and incubated with peroxidaseconjugated secondary anti-mouse or anti-rabbit antibodies for one hour at room temperature. The bands were visualized using enhanced chemiluminescence detection and exposure to film.

Real-time quantitative RT-PCR analysis. RNA extraction and cDNA conversion were performed. MG-63 cells in the logarithmic growth phase were placed into 6-well plates with a density of $2 \times 10^{5} / \mathrm{ml}$; and the cells were treated with different genistein concentrations ( 40,60 and $80 \mu \mathrm{mol} / \mathrm{l})$, with or without $1 \mu \mathrm{mol} / 1$ of GW9662, for two days. Total RNA was isolated with a TRIzol reagent (Takara Biotech, Dalian, China). cDNA was generated from total RNA by using a PrimeScript RT Master Mix kit (Takara Biotech). Quantitative real-time PCR was performed using LightCycler ${ }^{\mathrm{TM}} 480$ Real-Time system (Roche Applied Science, IN, USA) and SYBR Premix Ex $\mathrm{Taq}^{\mathrm{TM}}$ kit (Tli RNaseH Plus) (Takara Biotech). The threshold cycle $\left(C_{t}\right)$ value of each gene was measured from each RT sample. The $C_{t}$ value of $\beta$-actin was used as an endogenous reference for normalization purposes. Thus, the obtained $\mathrm{C}_{\mathrm{t}}$ value was normalized to negative control and was expressed as fold changes. The primers and reaction conditions used for the amplification are listed in Table I.

Statistical analysis. Statistical analysis was performed using SPSS 13.0 software (SPSS Inc., Chicago, IL, USA). The data were expressed as means \pm SD and the statistical differences between multiple groups were calculated by one-way ANOVA, followed by Dunnett's test. $\mathrm{P}<0.05$ values were considered statistically significant. The results from the in vitro studies are representative of at least three independent experiments.

\section{Results}

The effects of genistein, GW9662 and their combination on the viability of MG-63 cells. To determine the cytotoxicity of genistein on OS cells, we tested the effects of various doses of genistein on the viability of MG-63 cell line using CCK-8 assay. The cells were treated for 24,48 and $72 \mathrm{~h}$; and cell inhibition was found to be significant at 48 and $72 \mathrm{~h}$ (data at $24 \mathrm{~h}$ was not significant). As shown in Fig. 1A, cell growth was reproducibly inhibited by genistein treatment in a dosedependent manner. After 48-h treatment with 20, 40, 60, 80, 100 and $120 \mu \mathrm{mol} / \mathrm{l}$ of genistein, the cell survival rates were $103.4 \pm 2.7,76.7 \pm 3.7,54.6 \pm 6.6,40.0 \pm 3.5,33 \pm 4.8$ and $11.1 \pm 0.5$, respectively. After $72 \mathrm{~h}$ of MG-63 cell treatments with different genistein concentrations, the cell survival rates were 122.3 $\pm 7.1,87.2 \pm 5.6,48.8 \pm 1.9,26.7 \pm 2.9,17.7 \pm 2.3$ and $9.2 \pm 0.5$, respectively, inhibiting cell growth (Fig. 1A). Based on the data, the conditions used in 48-h treatments of genistein were selected for further studies.

Subsequently, we evaluated the effects of GW9662 - a potent specific antagonist of PPAR $\gamma$. It was found that low concentrations of GW9662 (0.01-1 $\mu \mathrm{mol} / \mathrm{l})$ played a weak role in impairing the proliferation of MG-63 cells (Fig. 1B). Similarly, Seargent et al (47) reported that GW9662 could directly prevent tumor cells by the PPAR $\gamma$-independent pathway. As a single agent, these results indicated that GW9662 was a growth inhibitor of OS cells. Therefore, $1 \mu \mathrm{mol} / 1$ of GW9662 was chosen for our studies, due to its minimal effects on MG-63 cells.

To assess whether the inhibition of genistein-induced cells are related to PPAR $\gamma$ activation (Fig. 1C), we investigated the effects of combining genistein and GW9662 on cell viability by CCK- 8 assay. The cells were treated with different concentrations of genistein $(20,40,60,80,100$ and $120 \mu \mathrm{mol} / \mathrm{l})$, with or without GW9662 ( $1 \mu \mathrm{mol} / \mathrm{l})$, for $48 \mathrm{~h}$. MG-63 cells showed comparable cell growth augmentation, when treated with genistein and GW9662. However, genistein treatment alone caused a significant increase in cell growth inhibition.

Therefore, to investigate the effects of PPAR $\gamma$ activation by genistein, our subsequent studies primarily focused on the MG-63 cell line, simulating different treatments for $48 \mathrm{~h}$.

PPAR inhibition attenuated genistein-induced inhibition of $M G-63$ cell proliferation. Cell proliferation was evaluated by detecting immunofluorescence for EdU. As shown in Fig. 1D and E, 48-h genistein treatments $(40,60$ and $80 \mu \mathrm{mol} / \mathrm{l})$ potently decreased the number of proliferating MG-63 cells. In contrast, combining different concentrations of genistein (40, 60 and $80 \mu \mathrm{mol} / \mathrm{l})$ and GW9662 $(1 \mu \mathrm{mol} / \mathrm{l})$ did not significantly affect the proliferation of MG-63 cells. Therefore, the inhibition of PPAR $\gamma$ with GW9662 significantly reduced the genistein-induced anti-proliferation activites of MG-63 cells. 
A

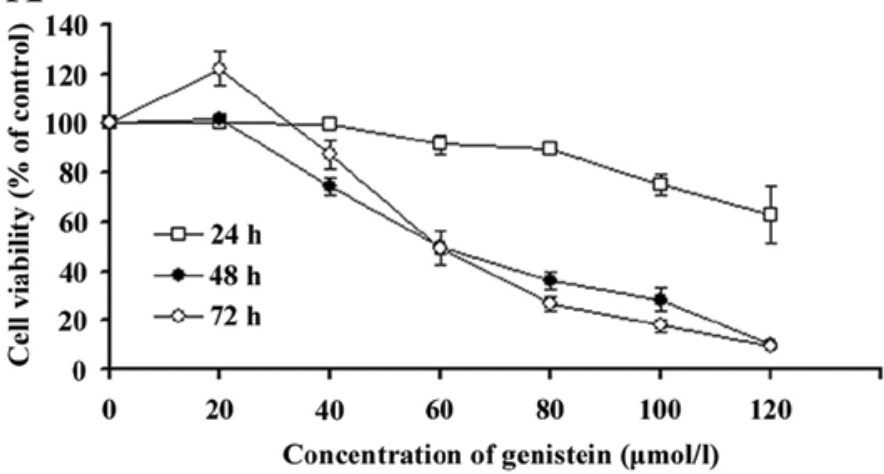

B

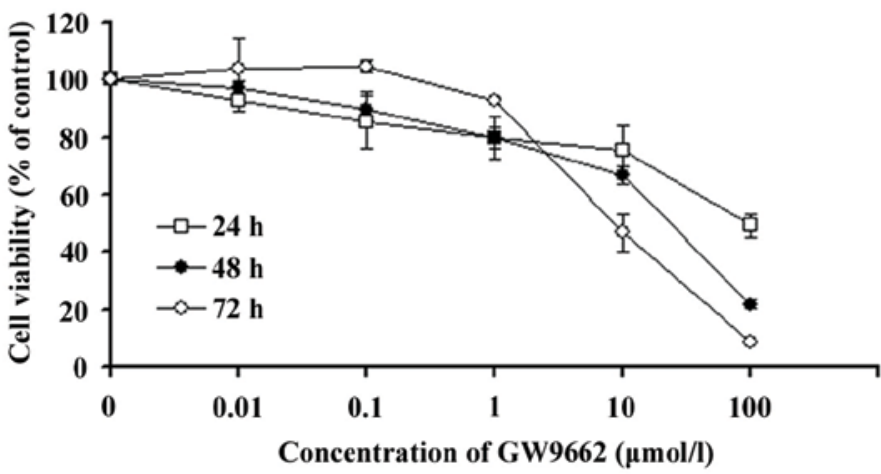

C
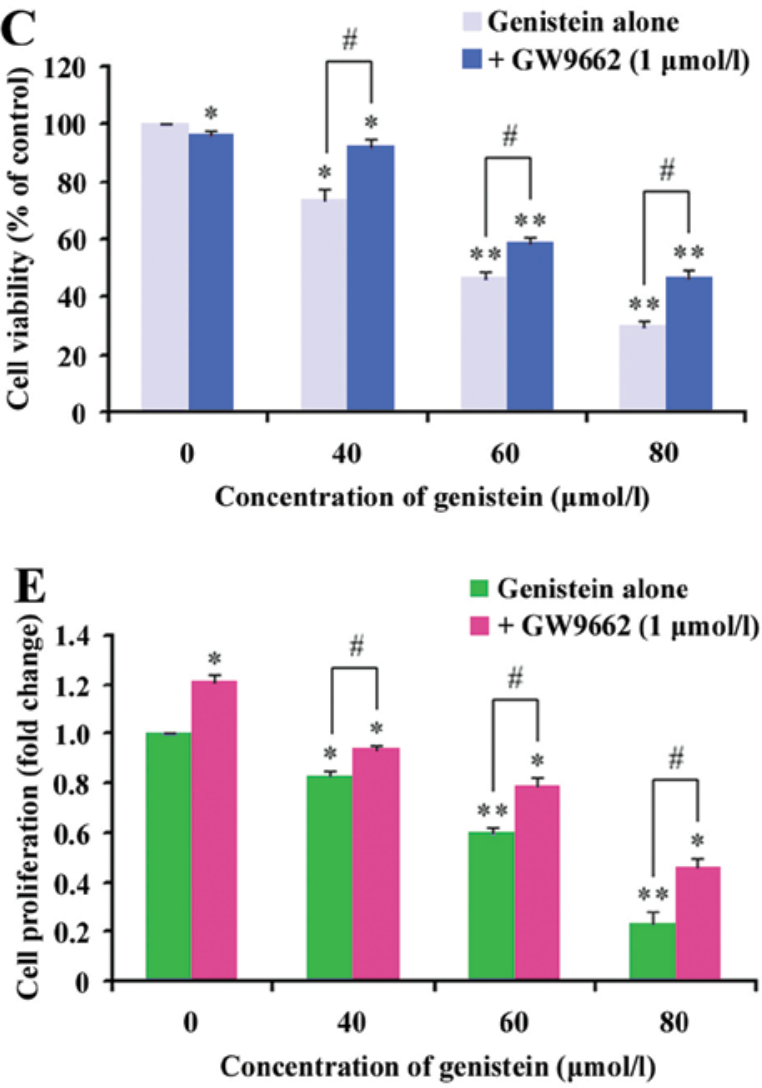

D
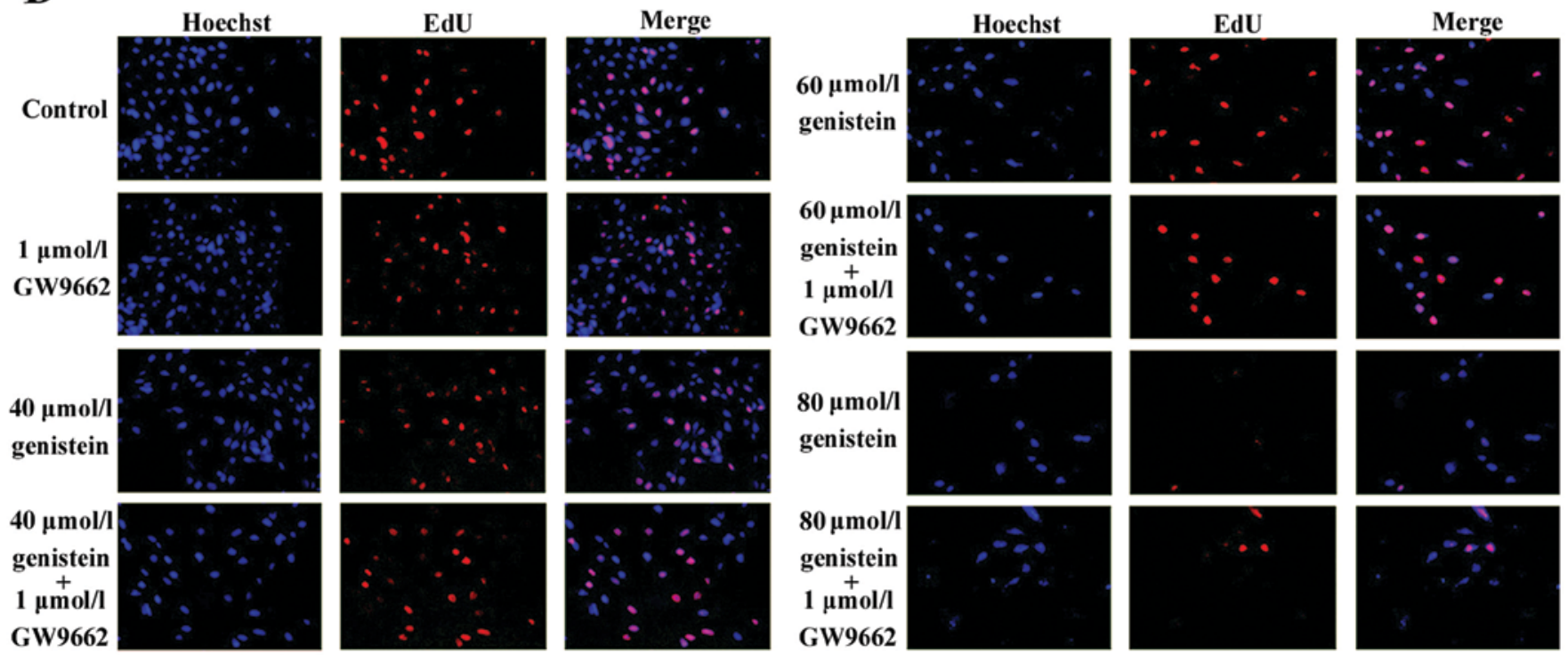

Figure 1. The human osteosarcoma MG-63 cell growth inhibition by genistein, GW9662 and their combination: (A) the effects of various doses of genistein on the viability of MG-63 cells after 24, 48 and 72 h; (B) the effects of various doses of GW9662 on the viability of MG-63 cells after 24,48 and 72 h; (C) the effects of various doses of genistein with $1 \mu \mathrm{mol} / 1$ of GW9662 on the viability of MG-63 cells after $48 \mathrm{~h}$. The total percentage of viable cells was measured by CCK- 8 assay. Data are expressed as mean \pm SD in three independent experiments. Bars marked with asterisks are significant with respect to the controls at ${ }^{*} \mathrm{P}<0.05$ and ${ }^{* *} \mathrm{P}<0.01$. The number of viable cells significantly increased, compared with the relative genistein group $\left({ }^{\#} \mathrm{P}<0.05\right)$. EdU assay of relative Hoechst stained cells and EdU add-in cells. (D) MG-63 cells were treated with different concentrations of genistein, combination or control. Forty-eight hours after treatment, EdU $(100 \mu \mathrm{mol} / \mathrm{l})$ was added and the cells were cultured for $2 \mathrm{~h}$. EdU and Hoechst staining were performed, as described in Materials and methods. At least 200 cells were counted per well. (E) Data are expressed as mean \pm SD in the representative experiments performed in triplicate. The proliferation rate of MG-63 cells, treated with different concentrations of genistein or the combined group, significantly decreased compared with the control ( $\mathrm{P}<0.05)$. The proliferation rate of the combination group significantly increased, compared with the relative genistein group $\left({ }^{\#} \mathrm{P}<0.05\right)$.

These data suggest that the result of activating the PPAR $\gamma$ mechanism partially caused genistein to lose its cell proliferation ability.
The effects of GW9662 on genistein-induced apoptosis in human OS MG-63 cells. Using fluorescence-activated cell sorting to quantify apoptosis, we observed that genistein as a 

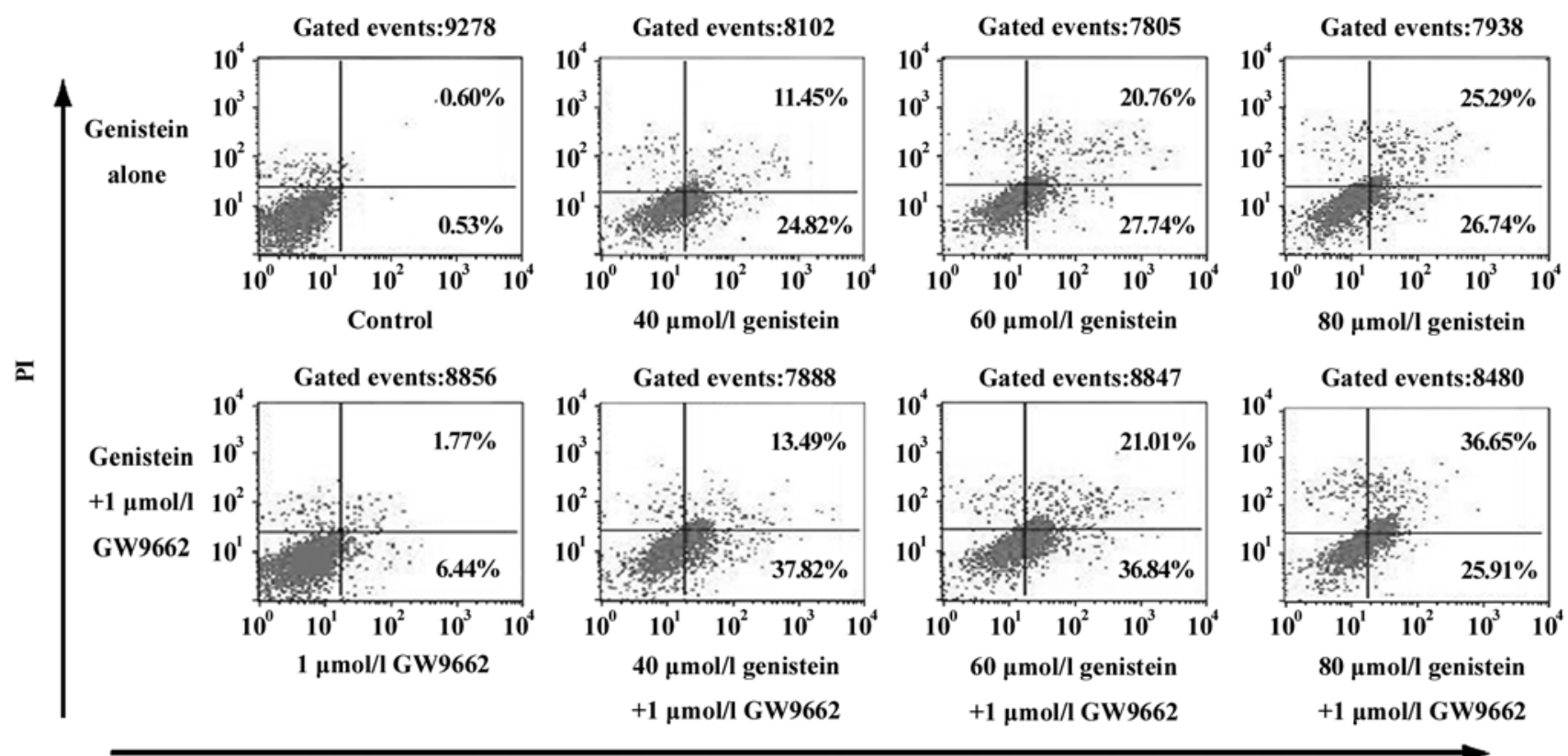

Annexin-V/FITC

Figure 2. Flow cytometry assay for apoptosis. The cells were stained with propidium iodide (PI) and Annexin V-fluorescein isothiocyanate (FITC) conjugate and measured by fluorescence activated cell sorting with an acquisition of 10,000 events. The gated events are shown above the dot blots. Apoptotic cells $\left(\mathrm{AV}^{+} / \mathrm{PI}\right)$ were monitored after treatment for $48 \mathrm{~h}$. GW9662 (1 $\left.\mu \mathrm{mol} / \mathrm{l}\right)$ significantly potentiated osteosarcoma cell apoptosis, which was induced by different genistein concentrations. The data shown here are representative of three different experiments.

single agent induced apoptosis in MG-63 cells dose-dependently (Fig. 2). DNA electrophoresis showed a more significant DNA ladder in MG-63 cells that underwent a combined treatment of genistein and GW9662. Flow cytometry experiments also showed that GW9662 can enhance genistein-induced OS cell apoptosis. The induction of genistein-induced apoptosis was dose-dependent and was unrelated to PPAR $\gamma$.

The effects of genistein and the combination of genistein and GW9662 on cell cycle progression. To detect if the suppressive effect of genistein can be caused by the specific perturbation of cell cycle-related events, the DNA content of genistein-treated and combination-treated MG-63 cells were measured using flow cytometry after PI staining of the nuclei. The $G_{1}$ and $S$ cell population significantly decreased in a dose-dependent manner and after 48-h exposure to genistein (Fig. 3), while cells were arrested in the $G_{2} / M$ phase of the cell cycle. Incubating with GW9662 reversed the effects of the $\mathrm{G}_{2} / \mathrm{M}$ cell cycle arrest caused by genistein.

The inhibitive effects of genistein on MG-63 cell growth via PPAR $\gamma$ pathway activation. PPAR $\gamma$ activation inhibits cell growth and causes both differentiation and apoptosis in a variety of cancer cell types (25). Therefore, in our present study, we used GW9662, a PPAR $\gamma$ inhibitor that can block PPAR $\gamma$ functions, to determine whether genistein prevents OS cell growth via the PPAR $\gamma$ pathway. Although GW9662 ( $1 \mu \mathrm{mol} / \mathrm{l})$ induced a decrease in cell growth, GW9662 treatment partially reversed the inhibitory effects of genistein based on the cell number; the related MG-63 cell protein expression was also changed.

To elucidate the effect of genistein in OS cell growth, proteins related to the PPAR $\gamma$ pathway were examined by western blot analysis. As shown in Fig. 4A and B, a stable level of PPAR $\gamma$ protein was observed in MG-63 cells after exposure to different genistein concentrations; however, the PPAR $\gamma$ protein expression was not altered by the GW9662 inhibitor. PTEN is a downstream target protein that plays a notable role in malignancy growth and causes the activation of the phosphoinositide-3 kinase/AKT (PI3K/Akt) signaling pathway (48). Fig. 4A and $\mathrm{C}$ shows that genistein (40, 60 and $80 \mu \mathrm{mol} / \mathrm{l})$ promoted the expression of the PPAR $\gamma$ target protein, PTEN, in a concentration-dependent manner. GW9662 treatment significantly decreased the PTEN expression caused by genistein; suggesting possible PPAR $\gamma$ pathway implications on the mechanisms responsible for the effects of genistein on OS cell growth.

Fig. 4D and E shows the real-time quantitative RT-PCR results of PPAR $\gamma$-related genes (PPAR $\gamma$ and PTEN). There was a prominent increase in PPAR $\gamma$ gene expression levels, as well as in the PTEN genes of MG-63 cells treated with genistein. GW9662 significantly inhibited the expression of these two genes induced by genistein. With $\beta$-actin constitutively expressed, its levels were not affected by genistein or the combined treatment. Thus, the real-time quantitative RT-PCR results support the previous observations of our western blot assay.

To further understand the downstream mechanism of the PPAR $\gamma$ pathway by genistein treatment, $\mathrm{G}_{2} / \mathrm{M}$ regulatory molecules were analyzed. Since genistein treatment perturbed the $\mathrm{G}_{2} / \mathrm{M}$ phase of the cell cycle, as assessed by flow cytometry, we examined the intracellular protein expression of the cell cycle regulating components at the $\mathrm{G}_{2} / \mathrm{M}$ boundary, such as $\mathrm{P} 21^{\mathrm{WAF} 1 /}$ ${ }^{\mathrm{CIP} 1}$ and Cyclin B1. As shown in Fig. 5A and B, a dramatic dose-dependent increase in the P $21^{\mathrm{WAF} 1 / \mathrm{CIP} 1}$ protein levels were observed with genistein, compared with the co-treatments. 


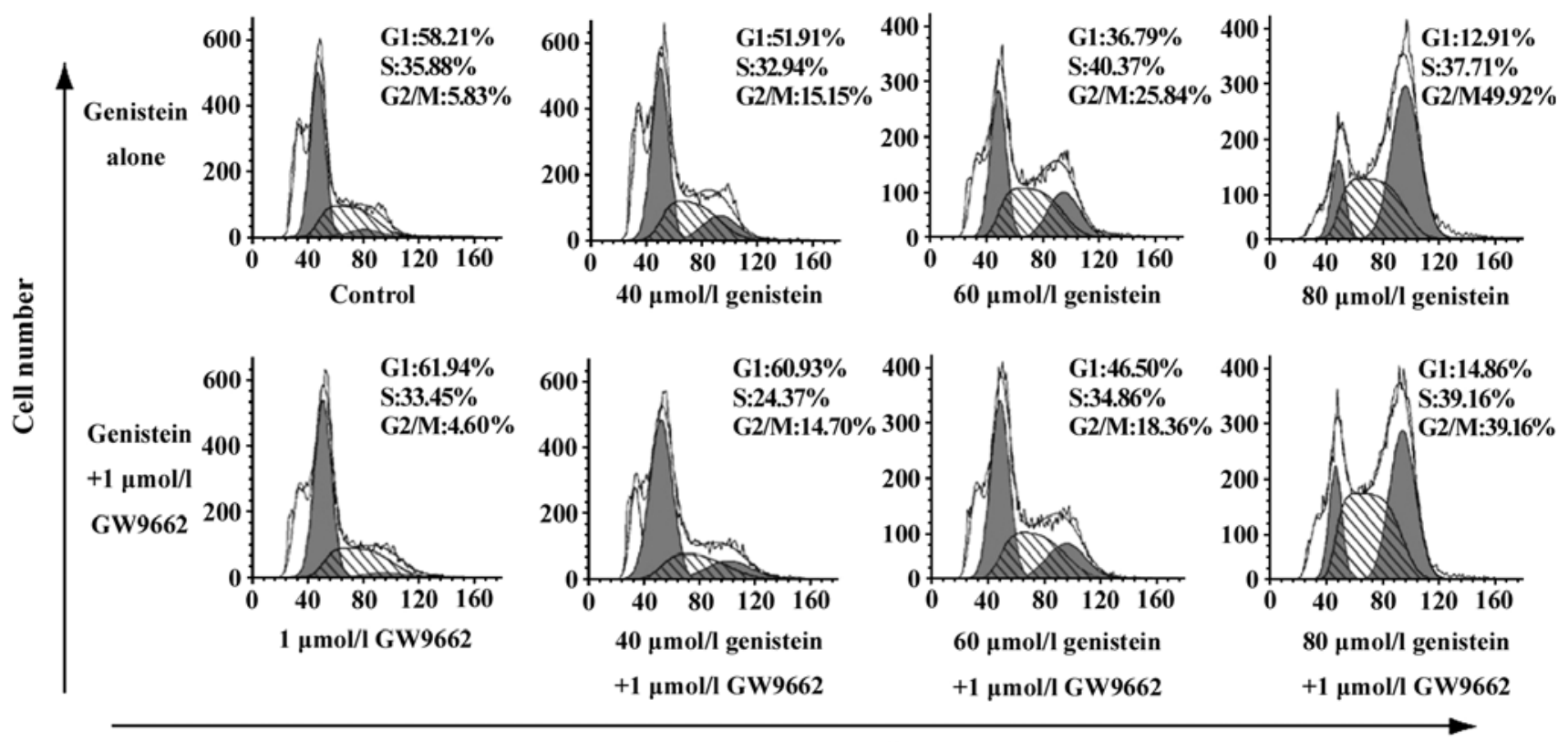

DNA content

\section{Channels (FL2-A)}
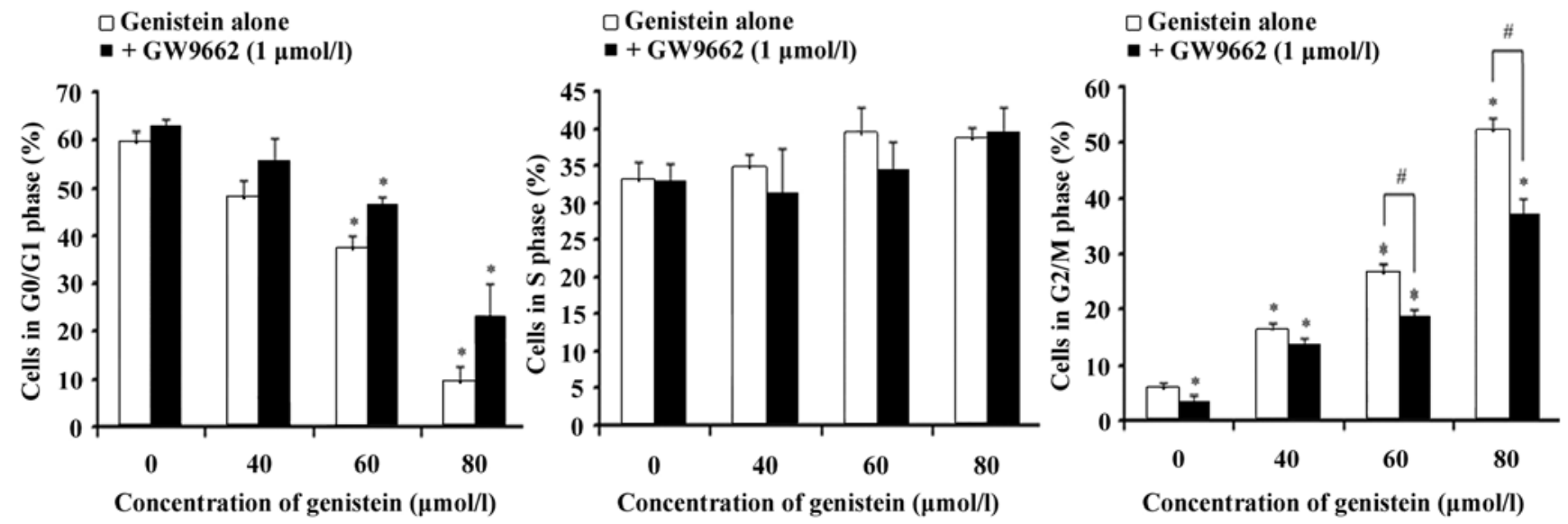

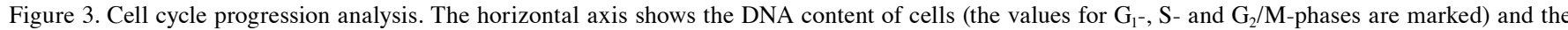
vertical axis represents the cell count. MG-63 cells were incubated for $48 \mathrm{~h}$ with genistein (40,60 and $80 \mu \mathrm{mol} / \mathrm{l})$ and/or GW9662 (1 $\mu \mathrm{mol} / 1)$. Cell cycle was analyzed by flow cytometry after propidium iodide staining. The data shown here are representative of three different experiments. Each bar graph represents the different phases of cell population ( $\mathrm{P}<0.05$ vs. control; ${ }^{\#} \mathrm{P}<0.05$ vs. relative combination group).

In contrast, Cyclin B1 levels (Fig. 5A and C) were reduced by either the reagent or the combined treatment, the former causing a more dramatic effect in a dose-dependent manner.

Several lines of evidence indicate that protein BCL-2 and survivin, related to the protein of PTEN $(49,50)$, were generally considered to be apoptosis inhibitors. These were frequently overexpressed in several types of human cancers, including OS. Parallel to the above observations, BCL-2 and survivin levels by genistein were decreased, as indicated by the significantly decreased levels of BCL-2 and survivin, even with the presence of GW9662 (Fig. 5D-F). While the inhibition of PPAR $\gamma$ repressed apoptosis-related protein levels, GW9662 did not reverse the genistein-induced effects on the promoted apoptosis, which was consistent with earlier findings.

Taken together, the data suggest that the PPAR $\gamma$ pathway was associated with the effects of genistein. Furthermore, genistein could significantly induce OS cell cycle arrest by activating PPAR $\gamma$, while it is probable for genistein-induced apoptosis to be independent from the PPAR $\gamma$ pathway.

\section{Discussion}

Genistein is one of the most important phytoestrogens; and its natural plant-derived compound is structurally similar to $17 \beta$-estradiol. Genistein is potentially regarded as an ideal chemotherapy agent for OS, due to its natural and safe applications, as well as its minimal side effects and relatively low cost. Numerous studies have indicated that genistein induced antitumor effects; through promoting cell death via $\mathrm{G}_{2} / \mathrm{M}$ cell cycle arrest $(51,52)$ and inducing apoptosis in various types of cancer cell lines (8-11). In human OS cell lines, genistein has shown its ability to inhibit tyrosine kinase and to affect cell growth dose-dependently inhibiting hyaluronan and 
A

\begin{tabular}{|c|c|c|c|c|c|c|c|c|}
\hline \multirow[b]{2}{*}{ Genistein } & \multicolumn{4}{|c|}{ Genistein $(\mu \mathrm{mol} / \mathrm{l})$} & \multicolumn{4}{|c|}{ Genistein + GW9662 ( $(\mu \mathrm{mol} / \mathrm{l})$} \\
\hline & - & 40 & 60 & 80 & - & 40 & 60 & 80 \\
\hline GW9662 & - & - & - & - & 1 & 1 & 1 & 1 \\
\hline PPAR $\gamma$ & $+\infty$ & 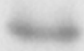 & wo & 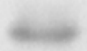 & $\rightarrow$ & - & - & - \\
\hline PTEN & & $=$ & $=$ & & & & $x^{2}$ & - \\
\hline
\end{tabular}

$\beta$-actin
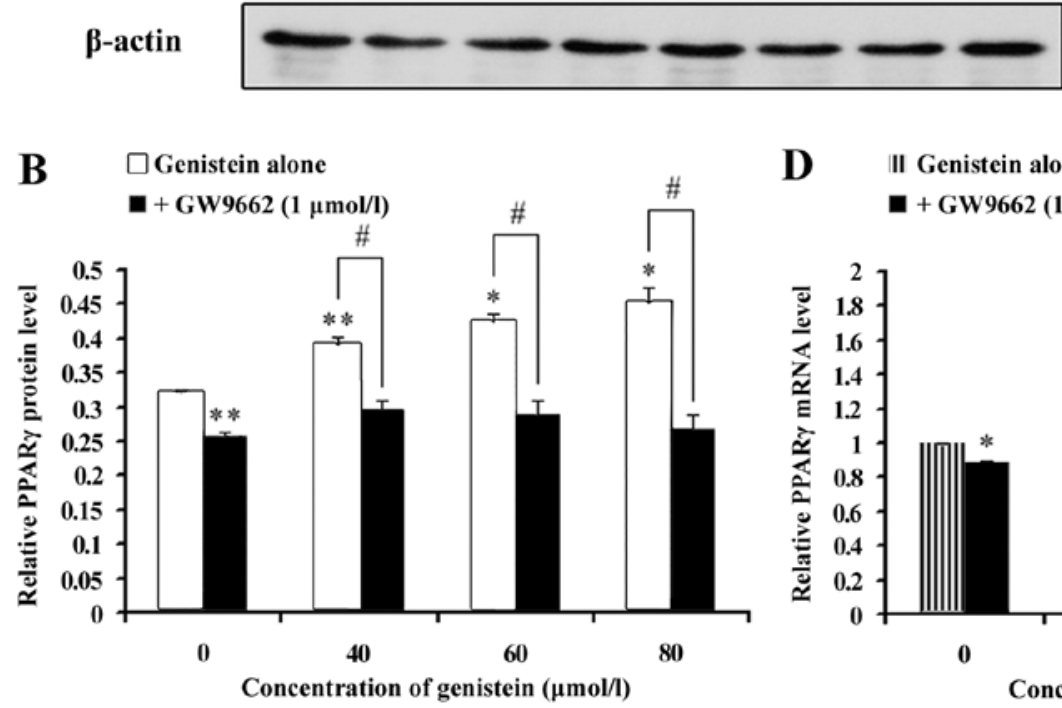

D II Genistein alone

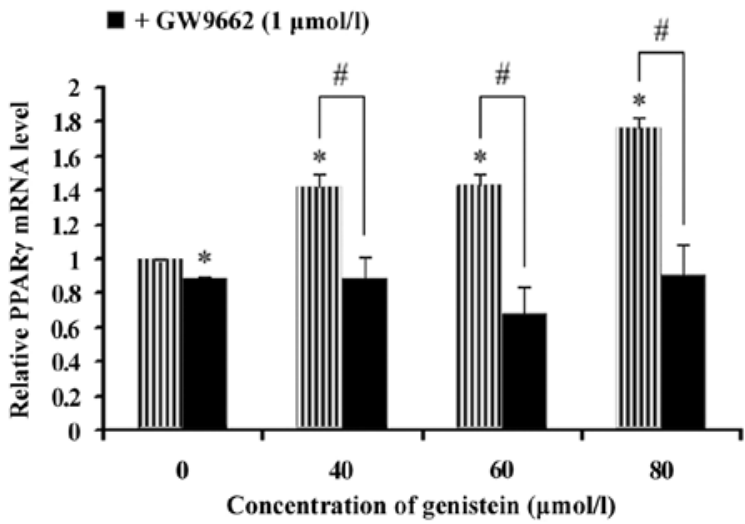

C $\square$ Genistein alone
$\mathbf{\square}+$ GW9662 (1 $\mu \mathrm{mol} / \mathrm{l})$

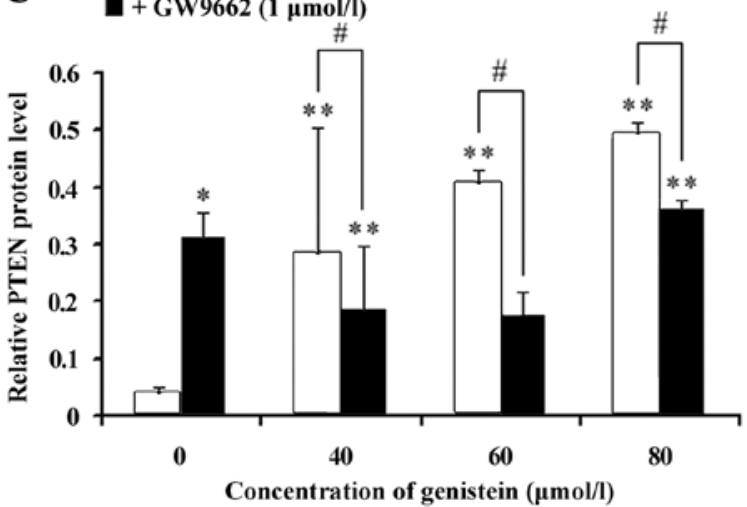

E III Genistein alone

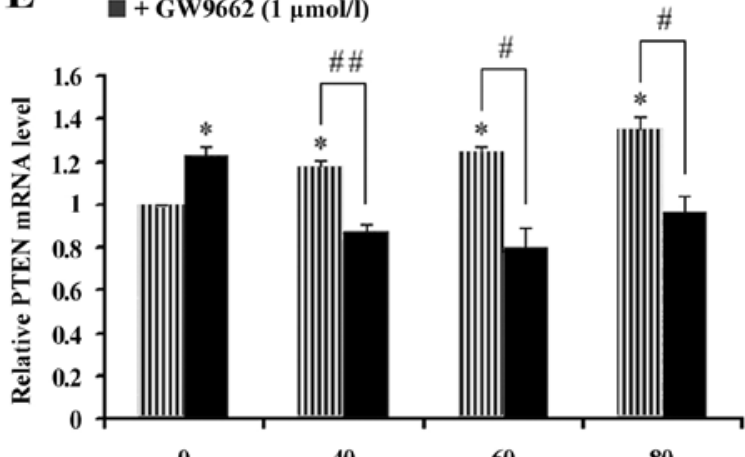

0

Concentration of genistein $(\mu \mathrm{mol} / \mathrm{l})$

Figure 4. Genistein ameliorates the overactivation of the PPAR $\gamma$ pathway. Cells were treated with genistein (40, 60 and $80 \mu \mathrm{mol} / \mathrm{l})$ and/or GW9662 (1 $\mu \mathrm{mol} / \mathrm{l})$; PPAR $\gamma$, PTEN and $\beta$-actin were detected using western blot analysis (A-C) and real-time PCR analysis (D and E). The expression of PPAR $\gamma$ and PTEN was examined by using SDS-PAGE gel electrophoresis and western blotting, and PPAR $\gamma$ and PTEN mRNA gene expression, as described in Materials and methods. Each bar represents the fold change \pm SD of target protein or mRNA normalized against $\beta$-actin. The data represent the results of the three independent experiments ( $\left({ }^{*}<0.05\right.$ vs. control; ${ }^{* *} \mathrm{P}<0.01$ vs. control; ${ }^{\#} \mathrm{P}<0.05$ vs. relative combination group; ${ }^{* \#} \mathrm{P}<0.01$ vs. relative combination group).

proteoglycan synthesis (13). Although some studies reported mechanisms involving ERs, some antitumor effects of estrogen-like compounds appear to be independent in their ability to bind with these receptors $(13,18,19)$. However, there are still underlying mechanisms pertaining to the antitumor effects of genistein on OS that are unclear.

PPAR $\gamma$ is a ligand-dependent nuclear transcription factor that belongs to the nuclear hormone receptor superfamily; which is involved in gene expression related metabolic processes, such as lipid and glucose homeostasis and important anti-inflammatory effects. Previous investigations revealed that PPAR $\gamma$ agonists have antitumoral properties in OS (37-51). PPAR $\gamma$ has been proposed as a possible target of genistein $(22,23)$. No previous studies were done on whether genistein could inhibit OS cell growth by activating PPAR $\gamma$.

In this study, phytoestrogen genistein inhibited cell survival dose-dependently and induce $\mathrm{G}_{2} / \mathrm{M}$ cell cycle arrest and apoptosis in the MG-63 OS cell line. With regards to the underlying mechanisms, the cell growth alternation of genistein and GW9662 and its inhibitory effects on MG-63 cells 
A
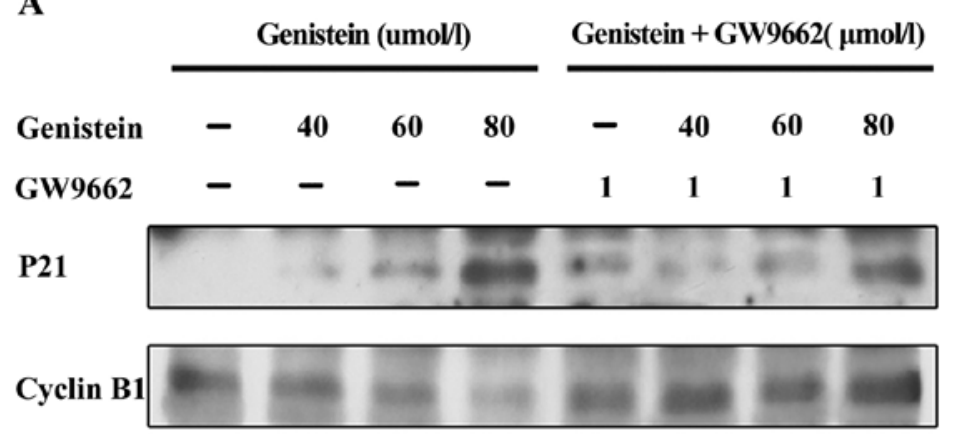

$\beta$-actin

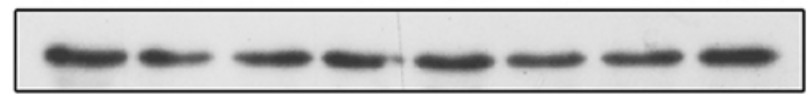

D
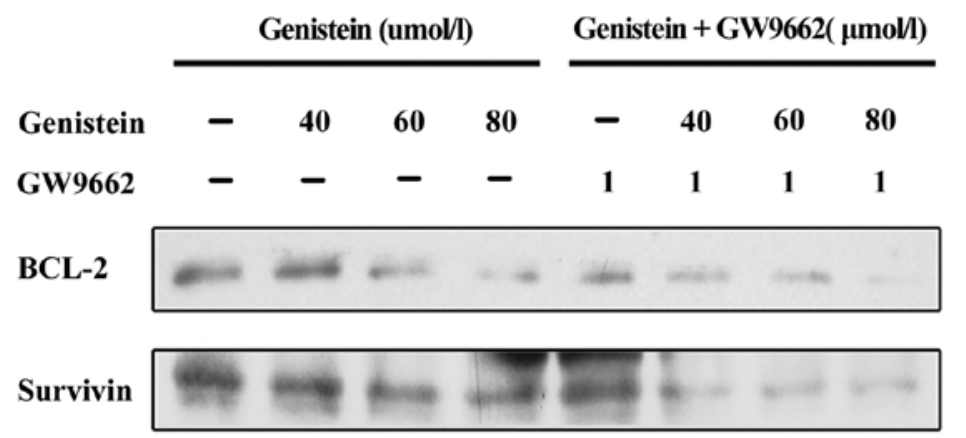

B-actin

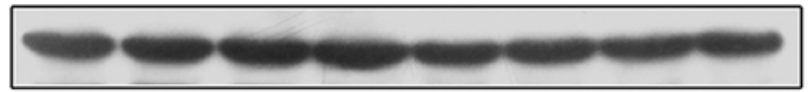

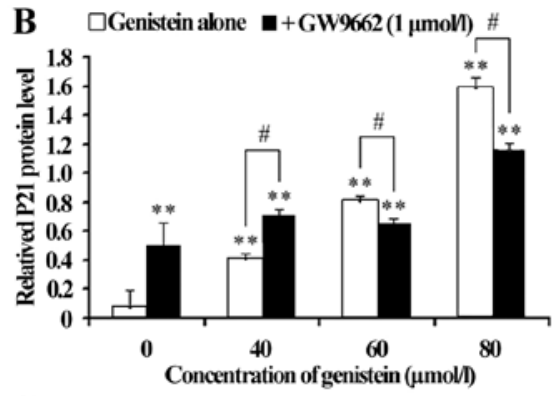
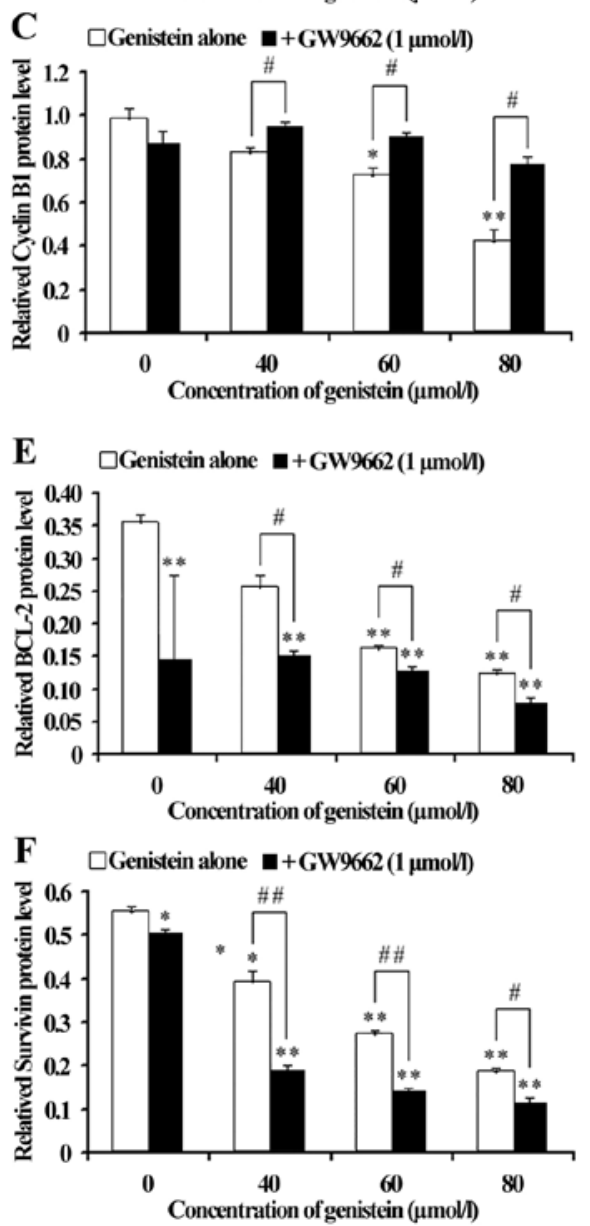

Figure 5. Effect of genistein on anti-apoptotic proteins and cell cycle regulatory proteins by activating PPAR $\gamma$. (A and D) Cells were treated with genistein $(40$, 60 and $80 \mu \mathrm{mol} / 1)$ and/or GW9662 (1 $\mu \mathrm{mol} / 1)$; and P21 ${ }^{\mathrm{WAF} / \mathrm{CIPl}}$, Cyclin B1, BCL-2, Survivin and $\beta$-actin were detected using western blot analysis. Expression of P21 ${ }^{\text {WAFI/CIP1 }}$ (B), Cyclin B1 (C), BCL-2 (E) and Survivin (F) was examined by using SDS-PAGE gel electrophoresis and western blotting, as described in Materials and methods. Each bar represents the fold change $\pm \mathrm{SD}$ of the target protein against $\beta$-actin. The data represent the results of the three independent experiments ( ${ }^{*} \mathrm{P}<0.05$ vs. control; ${ }^{* *} \mathrm{P}<0.01$ vs. control; ${ }^{\#} \mathrm{P}<0.05$ vs. relative combination group; ${ }^{\# \#} \mathrm{P}<0.01$ vs. relative combination group).

were observed to last for up to $48 \mathrm{~h}$, compared with genistein treatment alone. The data in our study demonstrated that the antitumor effect of genistein on MG-63 cells is, at least, partly dependent on PPAR $\gamma$ activation - since it was inhibited by the selective PPAR $\gamma$ antagonist, GW9662. Moreover, inhibiting PPAR $\gamma$ by GW9662 reversed the repressing effects of genistein on cell proliferation, but did not affect the genistein-induced cell apoptosis process.

To further explore the molecular mechanisms of the above results, we performed western blot and real-time quantitative RT-PCR analysis. PPAR $\gamma$ plays an critical role in tumorigenesis and differentiation (53). We found that PPAR $\gamma$ is highly expressed in genistein-treated MG-63 cells, which can be reversed by inhibiting statistically significant PPAR $\gamma$. We then investigated the downstream signaling effects of genistein and its co-application on MG-63 cells. PTEN, a well-known tumor suppressor, potently regulates the PI3K/Akt pathway, which is involved in cell proliferation and survival. Any altered expression of PTEN may contribute to the growth of osteosarcoma $(54,55)$. There is evidence that genistein exposure elevates PTEN levels via PPAR $\gamma$ activation (56). Our data confirmed that genistein treatment caused a significant increase of PTEN mRNA and protein expression and the accumulation of PPAR $\gamma$ proteins with the corresponding cell alterations. These results suggested that the ability of genistein to induce the PTEN to increase was dependent on PPAR $\gamma$ activation.

We then compared the gene and protein expressions in cells treated with genistein and cells treated with genistein 
and GW9662, to confirm our hypothesis that $\mathrm{S} / \mathrm{G}_{2} / \mathrm{M}$ cell cycle arrest and apoptosis stimulation were triggered by PPAR $\gamma$-mediated epigenetic events, caused by genistein. This hypothesis was based on current reports, where PTEN reactivates the transcription of $\mathrm{P} 21^{\mathrm{WAF} 1 / \mathrm{CIP} 1}$, Cyclin $\mathrm{B} 1$ is dominantly regulated by $\mathrm{P} 21^{\mathrm{WAF} 1 / \mathrm{CIP} 1}$ and that the reduced $\mathrm{BCL}-2$ and Survivin levels are regulated by the PPAR $\gamma$-mediated PTEN activation. Cell cycle progression is regulated through several different cyclin-dependent kinase (CDK) regulatory mechanisms, while other investigators demonstrated the ability of genistein to promote $\mathrm{G}_{2} / \mathrm{M}$ cell cycle arrest in human prostate carcinoma cells $(51,57)$. As a member of the Cip/Kip family of CDK inhibitors (CDKIs), $\mathrm{P} 21^{\mathrm{WAF} 1 / \mathrm{CIP} 1}$ is a cell cycle regulatory molecule involved in $\mathrm{G}_{2} / \mathrm{M}$ arrest. This molecule also downregulates the intracellular protein levels of Cyclin B1, which plays an essential role as a positive regulator in cell cycle progression, during the $\mathrm{G}_{2} / \mathrm{M}$ transition stage (57). By blocking PI3K/Akt signaling, PTEN promotes the nuclear movement of CDKIs and enhances the cell cycle inhibitory activities of $\mathrm{P} 21^{\mathrm{WAF} 1 / \mathrm{CIP} 1}$ (58). This hypothesis was clearly supported by the fact that GW9662 exhibits the capability of reversing the genistein-induced increase of $\mathrm{P} 21^{\mathrm{WAF} 1 / \mathrm{CIP} 1}$ and downregulating Cyclin B1, as determined by western blot and real-time quantitative RT-PCR analysis. On the other hand, BCL-2 is a key member of the BCL-2 family of apoptosis regulator proteins that have anti-apoptotic effects; and that the BCL-2 protein expression can be upregulated by genistein (59). Survivin also acts as an apoptosis inhibitor, which has been implicated in both apoptosis inhibition and mitosis regulation (60). BCL-2 and Survivin are frequently overexpressed in numerous types of cancer (61). Additionally, Ma and Wang (62) advocated that Survivin protein was directly correlated with Bcl-2 in colorectal cancer; and both proteins reacted on different apoptosis stages to jointly promote cancer development synergistically. For the past decade, many cancer research communities argued that PTEN decreased the expressions of BCL-2 and Survivin to induce apoptosis $(49,63)$. In the MG-63 cells, we found that genistein dramatically decreased the mRNA and protein expressions of BCL-2 and Survivin in a dose-dependent manner. Interestingly, GW9662 enhanced the antitumor effects of genistein in inhibiting BCL-2 and Survivin, rather than reversing genistein-induced results, by inactivating PPAR $\gamma$. The present study provides evidence that the activation of PPAR $\gamma$ could attenuate the degradation of BCL-2 and survivin by diverse mechanisms (64-66). In addition, we found that $1 \mu \mathrm{mol} / 1$ of GW9662 could slightly decrease the survival rate of the MG-63 cell line. Therefore, genistein-induced OS cell apoptosis may be independent of PPAR $\gamma$.

Overall, our results showed that genistein has PPAR $\gamma$ dependent inhibitive actions in the MG-63 cells, which was mainly presented by promoting $\mathrm{G}_{2} / \mathrm{M}$ arrest although this compound did not show any ability to increase apoptosis by PPAR $\gamma$ activation. Genistein-induced effects were associated to increased PPAR $\gamma$ transcriptional activity, concomitantly to a modulation of downstream target PTEN, to gradually fulfill growth inhibition that probably relates to PI3K/Akt signaling; thus, providing a novel mechanism for the post-translational modification of PPAR $\gamma$, which may have therapeutic implications for treating OS.

\section{Acknowledgements}

This study was supported by the National Natural Science Foundation of China (no. 81270052).

\section{References}

1. Yang Z, Kulkarni K, Zhu W, et al: Bioavailability and pharmacokinetics of genistein: mechanistic studies on its ADME. Anticancer Agents Med Chem 10: 1264-1280, 2012.

2. Banerjee S, Li Y, Wang Z, et al: Multi-targeted therapy of cancer by genistein. Cancer Lett 2: 226-242, 2008

3. Zhang Z, Wang CZ, Du GJ, et al: Genistein induces G2/M cell cycle arrest and apoptosis via atm/p53-dependent pathway in human colon cancer cell. Int J Oncol 1: 289-296, 2013.

4. Ullah MF, Ahmad A, Zubair H, et al: Soy isoflavone genistein induces cell death in breast cancer cells through mobilization of endogenous copper ions and generation of reactive oxygen species. Mol Nutr Food Res 4: 553-559, 2011.

5. Mizushina Y, Shiomi K, Kuriyama I, et al: Inhibitory effects of a major soy isoflavone, genistein, on human DNA topoisomerase II activity and cancer cell proliferation. Int J Oncol 4: 1117-1124, 2013.

6. Hwang KA, Kang NH, Yi BR, et al: Genistein, a soy phytoestrogen, prevents the growth of BG-1 ovarian cancer cells induced by 17 beta-estradiol or bisphenol A via the inhibition of cell cycle progression. Int J Oncol 2: 733-740, 2013.

7. Xia J, Cheng L, Mei C, et al: Genistein inhibits cell growth and invasion through regulation of mir-27a in pancreatic cancer cells. Curr Pharm Des 33: 5348-5353, 2014.

8. Hilakivi-Clarke L, Onojafe I, Raygada M, et al: Prepubertal exposure to zearalenone or genistein reduces mammary tumorigenesis. Br J Cancer 11: 1682, 1999.

9. Zhou JR, Mukherjee P, Gugger ET, et al: Inhibition of murine bladder tumorigenesis by soy isoflavones via alterations in the cell cycle, apoptosis, and angiogenesis. Cancer Res 22: 5231-5238, 1998.

10. Li C, Teng RH, Tsai YC, et al: H-Ras oncogene counteracts the growth-inhibitory effect of genistein in T24 bladder carcinoma cells. Br J Cancer 1: 80-88, 2004.

11. Yang $\mathrm{CH}$, Murti A, Pfeffer SR, et al: Interferon $\alpha / \beta$ promotes cell survival by activating nuclear factor $\kappa \mathrm{B}$ through phosphatidylinositol 3-kinase and Akt. J Biol Chem 17: 13756-13761, 2001.

12. Yamashita K, Suzuki M, Iwata H, et al: Tyrosine phosphorylation is crucial for growth signaling by tissue inhibitors of metalloproteinases. FEBS Lett 1: 103-107, 1996.

13. Nikitovic D, Tsatsakis AM, Karamanos NK, et al: The effects of genistein on the synthesis and distribution of glycosaminoglycans/proteoglycans by two osteosarcoma cell lines depends on tyrosine kinase and the estrogen receptor density. Anticancer Res 23 (1A): 459-464, 2003.

14. Morris C, Thorpe J, Ambrosio L, et al: The soybean isoflavone genistein induces differentiation of MG63 human osteosarcoma osteoblasts. J Nutr 5: 1166-1170, 2006.

15. Zhang B, Shi ZL, Liu B, et al: Enhanced anticancer effect of gemcitabine by genistein in osteosarcoma: the role of Akt and nuclear factor- $\kappa \mathrm{B}$. Anticancer Drugs 3: 288-296, 2010.

16. Liang $\mathrm{C}$, Li H, Shen $\mathrm{C}$, et al: Genistein potentiates the anticancer effects of gemcitabine in human osteosarcoma via the downregulation of Akt and nuclear factor-kappaB pathway. Anticancer Agents Med Chem 5: 554-563, 2012.

17. Nakamura A, Aizawa J, Sakayama K, et al: Genistein inhibits cell invasion and motility by inducing cell differentiation in murine osteosarcoma cell line LM8. BMC Cell Biol 1: 24, 2012.

18. Rickard DJ, Monroe DG, Ruesink TJ, et al: Phytoestrogen genistein acts as an estrogen agonist on human osteoblastic cells through estrogen receptors alpha and beta. J Cell Biochem 3: 633-646, 2003

19. Salvatori L, Caporuscio F, Coroniti G, et al: Down-regulation of epidermal growth factor receptor induced by estrogens and phytoestrogens promotes the differentiation of U2OS human osteosarcoma cells. J Cell Physiol 1: 35-44, 2009.

20. Djiogue S, Njamen D, Halabalaki M, et al: Estrogenic properties of naturally occurring prenylated isoflavones in U2OS human osteosarcoma cells: Structure-activity relationships. J Steroid Biochem Mol Biol 4-5: 184-191, 2010. 
21. Nakamura H, Wang Y, Kurita T, et al: Genistein increases epidermal growth factor receptor signaling and promotes tumor progression in advanced human prostate cancer. PLoS One 5 e20034, 2011.

22. Dang, ZC, Audinot V, Papapoulos SE, et al: Peroxisome proliferator-activated receptor gamma as a molecular target for the soy phytoestrogen genistein. J Biol Chem 2: 962-967, 2003.

23. Mezei O, Banz WJ, Steger RW, et al: Soy isoflavones exert antidiabetic and hypolipidemic effects through the PPAR pathways in obese Zucker rats and murine RAW 264.7 cells. J Nutr 5 : 1238-1243, 2003.

24. Xiang Q, Lin G, Fu X, et al: The role of peroxisome proliferatoractivated receptor- $\gamma$ and estrogen receptors in genistein-induced regulation of vascular tone in female rat aortas. Pharmacology 2 : $117-124,2010$

25. Youssef $\mathbf{J}$ and Badr M: Peroxisome proliferator-activated receptors and cancer: challenges and opportunities. $\mathrm{Br} \mathrm{J}$ Pharmacol 1: 68-82, 2011.

26. Willson TM, Lambert MH and Kliewer SA: Peroxisome proliferator-activated receptor gamma and metabolic disease. Annu Rev Biochem 70: 341-367, 2001

27. Berger $\mathrm{J}$ and Moller DE: The mechanisms of action of PPARs Annu Rev Med 53: 409-435, 2002

28. Bundscherer A, Reichle A, Hafner C, et al: Targeting the tumor stroma with peroxisome proliferator activated receptor agonists. Anticancer Agents Med Chem 7: 816-821, 2009.

29. Rumi MA, Ishihara S, Kazumori $\mathrm{H}$, et al: Can PPAR gamma ligands be used in cancer therapy? Curr Med Chem Anticancer Agents 6: 465-477, 2004.

30. Tontonoz P, Singer S, Forman BM, et al: Terminal differentiation of human liposarcoma cells induced by ligands for peroxisome proliferator-activated receptor gamma and the retinoid X receptor. Proc Natl Acad Sci USA 1: 237-241, 1997.

31. Kubota T, Koshizuka K, Williamson EA, et al: Ligand for peroxisome proliferator-activated receptor gamma has potent antitumor effect against human prostate cancer both in vitro and in vivo. Cancer Res 15: 3344-3352, 1998.

32. Asou H, Verbeek W, Williamson E, et al: Growth inhibition of myeloid leukemia cells by troglitazone, a ligand for peroxisome proliferator activated receptor gamma, and retinoids. Int J Oncol 5: 1027-1031, 1999.

33. Kitamura S, Miyazaki Y, Shinomura Y, et al: Peroxisome proliferator-activated receptor gamma induces growth arrest and differentiation markers of human colon cancer cells. Jpn J Cancer Res 1: 75-80, 1999.

34. Elstner E, Muller C, Koshizuka K, et al: Ligands for peroxisome proliferator-activated receptorgamma and retinoic acid receptor inhibit growth and induce apoptosis of human breast cancer cells in vitro and in BNX mice. Proc Natl Acad Sci USA 15 8806-8811, 1998.

35. Mueller E, Sarraf P, Tontonoz P, et al: Terminal differentiation of human breast cancer through PPAR gamma. Mol Cell 3: 465-470, 1998.

36. Chang TH and Szabo E: Induction of differentiation and apoptosis by ligands of peroxisome proliferator-activated receptor gamma in non-small cell lung cancer. Cancer Res 4: 1129-1138, 2000.

37. Ali AA, Weinstein RS, Stewart SA, et al: Rosiglitazone causes bone loss in mice by suppressing osteoblast differentiation and bone formation. Endocrinology 3: 1226-1235, 2005.

38. Rzonca SO, Suva LJ, Gaddy D, et al: Bone is a target for the antidiabetic compound rosiglitazone. Endocrinology 1: 401-406, 2004.

39. Rajkumar T and Yamuna M: Multiple pathways are involved in drug resistance to doxorubicin in an osteosarcoma cell line. Anticancer Drugs 3: 257-265, 2008

40. Yamaguchi K, Whitlock NC, Liggett JL, et al: Molecular characterisation of canine nonsteroidal anti-inflammatory drugactivated gene. Vet J 1: 89-95, 2008

41. He BC, Chen L, Zuo GW, et al: Synergistic antitumor effect of the activated PPARgamma and retinoid receptors on human osteosarcoma. Clin Cancer Res 8: 2235-2245, 2010.

42. Haydon RC, Luu HH and He TC: Osteosarcoma and osteoblastic differentiation: a new perspective on oncogenesis. Clin Orthop Relat Res 454: 237-246, 2007.

43. Haydon RC, Zhou L, Feng T, et al: Nuclear receptor agonists as potential differentiation therapy agents for human osteosarcoma. Clin Cancer Res 5: 1288-1294, 2002.

44. Yu LX, Yan HX, Liu Q, et al: Endotoxin accumulation prevents carcinogen-induced apoptosis and promotes liver tumorigenesis in rodents. Hepatology 4: 1322-1333, 2010.
45. Lv L, Xiao XY, Gu ZH, et al: Silencing USP22 by asymmetric structure of interfering RNA inhibits proliferation and induces cell cycle arrest in bladder cancer cells. Mol Cell Biochem 1-2: $11-21,2011$

46. Lu Q, Lu S, Gao X, et al: Norisoboldine, an alkaloid compound isolated from Radix Linderae, inhibits synovial angiogenesis in adjuvant-induced arthritis rats by moderating Notch1 pathwayrelated endothelial tip cell phenotype. Exp Biol Med 8: 919-932, 2012.

47. Seargent JM, Yates EA and Gill JH: GW9662, a potent antagonist of PPARgamma, inhibits growth of breast tumour cells and promotes the anticancer effects of the PPARgamma agonist rosiglitazone, independently of PPARgamma activation. Br J Pharmacol 8: 933-937, 2004.

48. Patel L, Pass I, Coxon P, et al: Tumor suppressor and antiinflammatory actions of PPARgamma agonists are mediated via upregulation of PTEN. Curr Biol 10: 764-768, 2001.

49. Wu ZX, Song TB, Li DM, et al: Overexpression of PTEN suppresses growth and induces apoptosis by inhibiting the expression of survivin in bladder cancer cells. Tumour Biol 1 : 9-15, 2007.

50. Mikhail M, Velazquez E, Shapiro R, et al: PTEN expression in melanoma: relationship with patient survival, Bcl-2 expression, and proliferation. Clin Cancer Res 14: 5153-5157, 2005.

51. Raffoul JJ, Wang Y, Kucuk O, et al: Genistein inhibits radiationinduced activation of NF-kappaB in prostate cancer cells promoting apoptosis and $\mathrm{G} 2 / \mathrm{M}$ cell cycle arrest. BMC Cancer 6: 107, 2006.

52. Ouyang G, Yao L, Ruan K, et al: Genistein induces G2/M cell cycle arrest and apoptosis of human ovarian cancer cells via activation of DNA damage checkpoint pathways. Cell Biol Int 12: 1237-1244, 2009.

53. Wagner ER, He BC, Chen L, et al: Therapeutic implications of PPARgamma in human osteosarcoma. PPAR Res: 956427, 2010.

54. Miao J, Wu S, Peng Z, et al: MicroRNAs in osteosarcoma: diagnostic and therapeutic aspects. Tumour Biol 4: 2093-2098, 2013.

55. Weng L, Brown J and Eng C: PTEN induces apoptosis and cell cycle arrest through phosphoinositol-3-kinase/Akt-dependent and -independent pathways. Hum Mol Genet 3: 237-242, 2001.

56. Waite KA, Sinden MR and Eng C: Phytoestrogen exposure elevates PTEN levels. Hum Mol Genet 11: 1457-1463, 2005.

57. Choi YH, Lee WH, Park KY, et al: p53-independent induction of $\mathrm{p} 21$, reduction of Cyclin $\mathrm{B} 1$ and $\mathrm{G} 2 / \mathrm{M}$ arrest by the isoflavone genistein in human prostate carcinoma cells. Jpn J Cancer Res 2: 164-173, 2000

58. Mayo LD and Donner DB: The PTEN, Mdm2, p53 tumor suppressor-oncoprotein network. Trends Biochem Sci 9: 462-467, 2002.

59. Zhang T, Wang F, Xu H-X, et al: Activation of nuclear factor erythroid 2-related factor 2 and PPAR $\gamma$ plays a role in the genistein-mediated attenuation of oxidative stress-induced endothelial cell injury. Br J Nutr 2: 223-235, 2013.

60. Halasova E, Adamkov M, Matakova T, et al: Expression of Ki-67, $\mathrm{Bcl}-2$, survivin and $\mathrm{p} 53$ proteins in patients with pulmonary carcinoma. Adv Exp Med Biol 756: 15-21, 2013.

61. Gao Q, Yang S and Kang MQ: Influence of survivin and Bcl-2 expression on the biological behavior of non-small cell lung cancer. Mol Med Rep 6: 1409-1414, 2012.

62. Ma Y and Wang HS: Correlations of Bcl-2 and survivin gene protein expressions in colorectal cancer. Applied Mech Mater 423-426: 362-365, 2013

63. Kumar P, Miller AI and Polverini PJ: p38 MAPK mediates gamma-irradiation-induced endothelial cell apoptosis, and vascular endothelial growth factor protects endothelial cells through the phosphoinositide 3-kinase-Akt-Bcl-2 pathway. J Biol Chem 41: 43352-43360, 2004.

64. Fong WH, Tsai HD, Chen YC, et al: Anti-apoptotic actions of PPAR-gamma against ischemic stroke. Mol Neurobiol 2-3: 180-186, 2010.

65. Ren Y, Sun C, Sun Y, et al: PPAR gamma protects cardiomyocytes against oxidative stress and apoptosis via Bcl-2 upregulation. Vascul Pharmacol 2-3: 169-174, 2009.

66. Kim YJ, Park KJ, Song JK, et al: The PPARgamma agonist protects cardiomyocytes from oxidative stress and apoptosis via thioredoxin overexpression. Biosci Biotechnol Biochem 12: 2181-2187, 2012. 